\title{
Implementation of Islamic Aqeedah Based Curriculum at Khoiru Ummah Tahfizh Plus Kindergarten
}

\author{
Neela Afifah*, Ahmad Suriansyah, Aslamiah \\ Graduate Program of Teacher Education for Early Childhood Education, Universitas Lambung Mangkurat, \\ Banjarmasin 70123, Indonesia
}

\begin{tabular}{|c|c|}
\hline ARTICLE INFO & A B STRACT \\
\hline \multirow[t]{2}{*}{$\begin{array}{l}\text { Article history } \\
\text { Received: June } \\
\text { Revised: August } \\
\text { Accepted: September } \\
\text { Keywords:Curriculum } \\
\text { Implementation, Islamic } \\
\text { Aqeedah }\end{array}$} & $\begin{array}{l}\text { Curriculum implementation is an application of concepts in the form of curriculum } \\
\text { documents into learning process. This study aims to identify and describe the } \\
\text { management curriculum,evaluation,and other factors that affect the implementation } \\
\text { of Islamic Aqeedah based curriculum. This research uses qualitative approach. The } \\
\text { object of is Islamic Aqeedah based curriculum and the subjects are teachers and } \\
\text { students used triangulation data with cross-site data analysis. The results of the } \\
\text { study show that learning isdesigned by making curriculum guidelines, academic } \\
\text { calendars, determining themes, learning schedules and daily activity. Organization is } \\
\text { implemented by making organizational structure and daily task distribution. Learn- } \\
\text { ing implementation uses discovery learning which is calledby 'talqiyyanfikriyyan' } \\
\text { method by integrating all knowledges into Islamic Aqeedah. The form of } \\
\text { controllings are supervision. Learning evaluation uses connecting books or diaries. } \\
\text { The factors that influence the implementation of the curriculum are teachers, } \\
\text { parents, students, environment and government. }\end{array}$ \\
\hline & $\begin{array}{l}\text { CC (1) () } 2019 \text { The Authors. Journal of K6, Education, and Management (j- } \\
\text { K6EM). ISSN: } 2580-2135 \text {. Published by Graduated Program of Master } \\
\text { of Teacher Education for Early Childhood Education, Universitas } \\
\text { Lambung Mangkurat, Banjarmasin 70123, Indonesia. This is an open access article under the } \\
\text { CC-BY-SA license. }\end{array}$ \\
\hline
\end{tabular}

* Correspondence: Neela Afifah; E-mail: neela.afifah@yahoo.com 


\section{Introduction}

Education is an important factor in the existence of a civilization. Education in Islam is always closely related to unity which is based on Aqeedah (belief) and is closely related to faith.

Curriculum is an educational design that summarizes all learning experiences provided for students at school. In a curriculum, philosophy, values, knowledge must be integrated with educational actions (Suhaimi \& Rinawati, 2018).

Early Childhood Education is the first educational institution, and its existence is very strategic to instill religious values, especially good Islamic faith, and to foster a religious spirit for children, so that they become obedient, accustomed, and caring for all rules the religion has taught to him.

Whereas today, parents are very easy to hand over children's education fully to the school, Western culture which is very close to children also affects their lives from various aspects such as how they dress, how they get along with others, their behavior, until their mindset. Even though good education can be realized when it's based on a strong religious foundation and supported by the balance of education between school and at home (cooperation).

Every curriculum designed must reflect the school's vision, mission and goals. The curriculum is also important to innovate, update and develop the previous curriculum to get better in the future (Andriyani, Ngadimun, \& Suriansyah, 2018), because success in achieving educational goals is determined by the foundation in learning and the elements within it, which are students, educators, interaction between students and educators, environment, material / educational content (Salasiah, Asniwati, \& Effendi, 2018).

The curriculum for moral and religious development only revolves around children's daily activities, starting from activities in the school environment, socializing with peers, and habituation to routine activities related to habituating religious rules for oneself, while aqeedah is a lesson that must be firstly instilled in children before the subject of other services in Islamteachings. As the first pillar of Faith is Faith in God, and as the first pillar of Islam is the Creed. Therefore, educating early childhood with the correct aqeedah will result in strong faith as well as the curriculum made by Khoiru Ummah, where Islamic Aqeedah is the basis that they must firstly cultivate with children before other sciences.

Based on the description above, the purpose of this study is to analysis and describe planning, organizing, actuating, controlling, and evaluation of Islamic Aqeedah Based Curriculum at the Khoiru Ummah Tahfizh plus kindergarden. Analysis factors affecting the implementation of Islamic Aqeedah Based curriculum at Khoiru Ummah Tahfizh plus kindergarden.

\section{Research Methods}

This research was conducted from September to December 2018 in the Tahfizh Plus School Khoiru Ummah Banjarmasin and Banjarbaru Kindergarten. Qualitative research is a descriptive study and uses analysis using multi-site methods. This study is intended to obtain an overview of the implementation of the curriculum used by Khoiru Ummah independently based on Islamic Aqeedah. As for the sample in this study were kindergarten A class students and kindergarten B class students totaling 53 people at STP Khoiru Ummah Banjarmasin and 45 people at STP Khoiru Ummah Banjarbaru because at this level more clearly visible developments in the implementation of the Islamic Aqidah-based curriculum, and the form of evaluation is also more concrete than the children in the Playgroup class. Data collection techniques in this study used observation, interviews and documentation. As for the objects of observation are the place, teaching staff, education staff and students, as well as learning activities. The object of the interview is related to how the planning, organization, implementation, supervision, evaluation in the implementation of Islamic aqidah-based curriculum and the factors that influence it. While the documentation data sought is the Islamic Aqidah Curriculum Based Guidelines, Syllabus and student liaison books (Sugiyono, 2017). The following is Figure I. Cross Site Data Analysis used in this study:

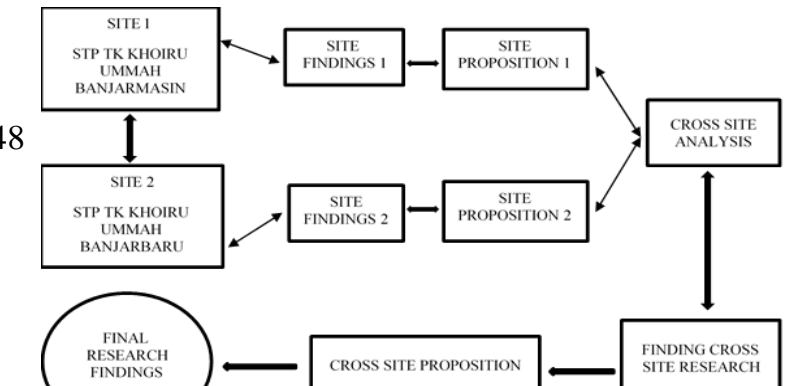


Figure I.Cross Site Data Analysis

\section{Results and Discussion}

This study was conducted at Tahfizh Plus TK Khoiru Ummah Banjarmasin School and Khoiru Um- mah Banjarbaru Tahfizh Plus Kindergarten School based on a letter from the Chair of the Early Childhood Education Teacher Education Master Study Program at Lambung Mangkurat University Number: 46 / UN8.4.I.6.5 / SP / 2018 dated 28 September 2018, regarding permission for research / observation. Based on research permission starting from 28 September 2018 until 28 December 20I8, data collection was carried out at both the STP TK KhoiruUmmah Banjarmasin and Banjarbaru.

Comparison of data from STP TK Khoiru Ummah Banjarmasin (site I) and STP TK Khoiru Ummah Banjarbaru (site 2) are shown in the following table:

Table I. Comparative Findings Site I and Site 2

\begin{tabular}{|c|c|c|c|}
\hline NO. & FOKUS PENELITIAN & DATA SITUS I & DATA SITUS 2 \\
\hline I. & $\begin{array}{l}\text { What is the planning of learning } \\
\text { in the Islamic faith-based curric- } \\
\text { ulum at the Khoiru Ummah } \\
\text { Tahfizh Plus TK School? }\end{array}$ & $\begin{array}{l}\text { a. Islamic Aqeedah Based Curric- } \\
\text { ulum } \\
\text { b. Academic Calendar } \\
\text { c. Learning Schedule } \\
\text { d. Daily Activity Plan } \\
\text { e. Determine the themes that are } \\
\text { filled in the academic calendar. }\end{array}$ & $\begin{array}{l}\text { a. Islamic Aqeedah Based Curricu- } \\
\text { lum } \\
\text { b. Academic Calendar } \\
\text { c. Learning Schedule } \\
\text { d. Determine the theme for } 2 \\
\text { semesters (I year) } \\
\text { e. Make planning or preparation } \\
\text { for learning every once a month }\end{array}$ \\
\hline 2. & $\begin{array}{l}\text { How is the Organizing of Islam- } \\
\text { ic Aqeedah Based Curriculum } \\
\text { carried out by the Khoiru Um- } \\
\text { mahTahfizh Plus TK Schol? }\end{array}$ & $\begin{array}{l}\text { a. Division of Tasks / Responsi- } \\
\text { bilities to all teachers and em- } \\
\text { ployees. }\end{array}$ & $\begin{array}{l}\text { a. Division of Tasks / Responsi- } \\
\text { bilities to all teachers and em- } \\
\text { ployees. }\end{array}$ \\
\hline 3. & $\begin{array}{l}\text { How is actuating learning in the } \\
\text { Islamic Aqeedah Based Curricu- } \\
\text { lum at the Khoiru Ummah Tah- } \\
\text { fizh Plus TK School? }\end{array}$ & $\begin{array}{l}\text { a. Using Discovery Learning } \\
\text { Learning Strategies } \\
\text { b. Using learning media according } \\
\text { to the theme. Example: Cooking } \\
\text { Class, the media prepared is } \\
\text { cooking utensils, cooking ingre- } \\
\text { dients. } \\
\text { c. Perform stages of science learn- } \\
\text { ing as the } 2013 \text { curriculum } \\
\text { (Observing, Asking, Exploring, }\end{array}$ & $\begin{array}{l}\text { a. Using Discovery Learning } \\
\text { Learning Strategies } \\
\text { b. Using learning media according } \\
\text { to the theme. Example: Tongue } \\
\text { to taste, then the prepared me- } \\
\text { dia is salt, sugar, and others. } \\
\text { c. Perform stages of science learn- } \\
\text { ing as the } 2013 \text { curriculum } \\
\text { (Observing, Asking, Exploring, } \\
\text { Associating, and Communica- }\end{array}$ \\
\hline 4. & $\begin{array}{l}\text { How is controlling learning with } \\
\text { the Islamic Aqidah-based curric- } \\
\text { ulum at the Khoiru Ummah } \\
\text { Tahfizh Plus TK School? }\end{array}$ & $\begin{array}{l}\text { Direct supervision from the prin- } \\
\text { cipal and chairman of the founda- } \\
\text { tion, the results of which will be } \\
\text { followed up at the evaluation } \\
\text { meeting. }\end{array}$ & $\begin{array}{l}\text { Direct supervision from the prin- } \\
\text { cipal. Because of his involvement } \\
\text { in learning with the status as hom- } \\
\text { eroom teacher TK B, it will pro- } \\
\text { vide direct control of the course of } \\
\text { learning everv dav }\end{array}$ \\
\hline 5. & $\begin{array}{l}\text { What is the evaluation of learn- } \\
\text { ing in the Islamic Aqeedah Based } \\
\text { Curriculum at the Khoiru Um- } \\
\text { mah Tahfizh Plus TK School? }\end{array}$ & $\begin{array}{l}\text { a. There is an anecdote } \\
\text { b. Weekly evaluation } \\
\text { c. Monthly evaluation } \\
\text { d. Semester evaluation with distri- } \\
\text { bution of report cards }\end{array}$ & $\begin{array}{l}\text { a. Spontaneous evaluation of } \\
\text { students without documenta- } \\
\text { tion. } \\
\text { b. Monthly evaluation for learn- } \\
\text { ing. } \\
\text { c. Semester evaluation conducted } \\
\text { by parents and homeroom. }\end{array}$ \\
\hline
\end{tabular}




\begin{tabular}{|c|c|c|c|}
\hline 6. & $\begin{array}{l}\text { What are the factors that influ- } \\
\text { ence the implementation of the } \\
\text { Islamic Aqeedah Based Curricu- } \\
\text { lum at the Khoiru UmmahTah- }\end{array}$ & \begin{tabular}{|ll} 
a. & Teacher \\
b. Parents \\
c. Students \\
d. Government
\end{tabular} & $\begin{array}{l}\text { a. Teacher } \\
\text { b. Parents }\end{array}$ \\
\hline
\end{tabular}

\section{Planning of Learning in the Islamic Aqeedah faith- based Curriculum}

Learning planning is carried out by creating an academic calendar that is modified based on Khoiru Ummah curriculum, making learning schedules according to the conditions of each school, and making daily activity units which are only done by STP TK Khoiru Ummah Banjarmasin.

On site I and site 2, the learning planning process is mature, because it appears to be very systematic in its implementation, runs regularly and is very organized. It's just that the difference between the two lies in the management of the plan, site $I$ is very neat documentation and administration and the planning made by the teacher must go through a fairly rigorous selection stage, while site 2 has not been properly administered, because it takes a long time to plan learning for one semester as researchers have ever said that they plan every month, which is then typed and pasted on the school classroom walls.

While the principles that must be considered in developing planning are: (I) The formulation of competencies in preparation for teaching must be clear. The more concrete the competencies, the easier it is to be observed and the more precise the activities that must be carried out to shape these competencies. (2) Preparation of teaching must be simple and flexible and can be implemented in learning activities and the formation of competency of students. (3) Activities prepared and developed in teaching preparation must support and be in accordance with established competencies. (4) The teaching preparation developed must be completed and comprehensive, as well as clear its achievements. (5) There must be coordination between the implementing components of the school program, especially if learning is carried out in a team teaching or moving class (Mulyasa, 2004).

Five important planning components delivered by Mulyasa were carried out by these two sites. The competency that is to be achieved is because it comes from the same curriculum manual, only site I decreases it in the form of daily activity unit while site 2 is not in the form of daily activity unit but rather in monthly activity unit. All teaching preparations conducted are always interesting and support the achievement of children's competence.

\section{Organizing of Islamic Aqeedah Based Curriculum}

Organizing in Islamic Aqeedah based curriculum on site $\mathrm{I}$ is managed by the Principal. Before starting the new school year, the principal analysis of human resource needs analysis by determining human resources who have the same vision and mission to achieve the goals or output of graduates from Khoiru Ummah Tahfizh Plus TK School. Then the principal distributes tasks to all teachers and employees, related to the process of teaching and learning activities every day. So that everyone has responsibility for what has been mandated. The principal also asks all teachers to make andaily activity planin which it must get approval from the principal before being implemented. If the daily activity plan is not in accordance with the learning objectives or vision of Khoiru Ummah, then the teacher must correct it.

The principal also asks all teachers to take part in parenting and learning activities, to be able to improve the knowledge and teacher qualityand improve the recitation of Qur'an from each teacher, because based on the observations and hearing of the researchers, the quality of recitation for some teachers is not in accordance with the rules. This can be proven from the data of the teacher's graduation in participating in the Koran teacher certification activities with Ummi Method, which is only 3 people who have a Shahadah (certificate), and the principal also conducts regular scheduling for evaluation meetings with the teacher.

Based on the results of the data that the researchers got, the school principal had organized the Islamic Aqeedah curriculum learning well. With the planning, division of tasks, implementation and evaluation, it then makes improvements and innovations, and helps the school to achieve the target or learning objectives.

Khoiru Ummah Banjarmasin also distributes tasks listed in the foundation management team, such as: PJ Curriculum which is tasked with performing problem solving on HR and implementing learning in the field. Then public relations, cooperation, PJ PAUD, PJ SD, and PJ SMP.

Based on the results of the interview, he said that to organize the learning path in Islamic aqidah-based curriculum at STP TK Khoiru Ummah Banjarbaru, he did the division of tasks to all teachers and employees. The division of tasks referred to, namely: (I) Deter- 
mining PJ Outing every month; (2) Determining PJ who prepares snacks or meals for students to take breaks in turns; (3) Determining picket schedules for teachers who maintain the gate for students' arrival and return of students; (4) Determining tahfizh guidance for students; and (5) Administration asked to prepare all the materials needed for teaching and learning activities, whether it's duplicating materials or related to stationery.

Tahfizh Plus Khoiru Ummah Banjarbaru School also collaborates with related parties, such as cooperation with tahfiz houses related to parenting seminars and Hajj rituals guided by Mr. Abdul Karim. Then it involves the closest mosque, for Friday prayers every week (especially for elementary students), and cooperation with Poltekes to borrow buildings that are commonly used to distribute student report cards. Because the distribution of report cards is one between PAUD and SD, the end of semester activities are always carried out outside the school.

If it is related to curriculum organization according to Tyler, then the two sites that use Islamic Aqeedah Early Childhood Education Curriculum are included in horizontal organizations, namely: Integration, namely Integration Curriculum which explains that the integration of subjects is of high value for student learning and retention, because horizontally integration expands students' views on knowledge. This means that integration allows students not only to understand the relationship between one subject and another subject, but also between school knowledge and learning experiences outside of school, as well as between the curriculum with the talents, interests and personal needs of students.

Integration is built to highlight the horizontal relationship of various student learning experiences, both in one subject and between subjects, because learning will be more effective if the facts and principles of a subject or field of study are related to the facts and principles of subjects or other fields of study. Through integration, educators show a horizontal relationship between learning experiences so that students have a comprehensive, broader and deeper view, not only conceptually but also applied knowledge, skills and values in real life (Torang, 2016).

\section{Actuating Learning in the Islamic Aqeedah Based Cur- riculum}

Based on the implementation of Islamic Aqeedahbased learning in STP Khoiru Ummah Banjarmasin, they use discovery learning, or learning by doing, or what they commonly call by 'talqiyyanfikriyyan' strategy because the addition of TalqiyyanFikriyyan method is the learning by doing strategy that was integrated into Islamic aqeedah, and the learning media used is in accordance with the theme being studied. The concept of learning finds that it is actually similar to the idea of learning by doing which was initiated by an educational figure, John Dewey. This concept emphasizes the importance of learning something while practicing directly (Haenilah, 20I5).

As the results of research with one of the variables is the development of child independence through practical methods direct activities that show the results of research that children's activities in carrying out learning activities develop children's independence through direct practice methods of practical life learning activities so that the average class reaches the criteria very active $(\mathrm{SA})$ and classics are in the very active (SA) category (Safitri, Ahmad, \& Saleh, 2018). Therefore it is very important to use direct practice by using STP Khoiru Ummah to make children actively involved and get quick and real understanding so that children can be more skilled. Because a person's success is determined by 20 percent of his hard skills and 80 percent of his soft skills. This means that the quality of education has been largely determined by the character of the students. Therefore, the focus on character development must be prioritized (Sukriani, Huda A.Y, Arifin, \& Suriansyah, 2017).

\section{Controlling Learning with the Islamic Aqidah-based Curriculum}

Supervision on site I was carried out by the principal by occasionally monitoring the activities of teaching and learning process in the field, and helping teachers complete and straighten out adverse events in the classroom. The principal also conducts daily and weekly evaluations to control the course of the learning process. Khoiru Ummah Center has also visited or supervised Tahfiz Plus Khoiru Ummah Banjarmasin School once.

The controlling of the chairman of the foundation or manager is once a week, to see firsthand the condition of Khoiru Ummah Tahfizh School in Banjarmasin. In addition to coming to school, he also actively monitors through social media such as Whatsapp group where there are principals, teachers and parents of students, and he himself as chairman of the foundation. Because the group is one of the communication media for all parties to provide information related to education. STP Khoiru Ummah Banjarmasin also rou- 
tinely provides monthly reports on the development of schools to Khoiru Ummah Center. On request, Khoiru Ummah center can also supervise directly to Banjarma$\sin$.

Communication is an activity that is always done by everyone wherever he is, because communication is one of the needs of humans as social beings. In fact, communication can be said to be the heart of life in an organization, without communication, the organization will die, at least it cannot develop optimally because it states that communication is the key to successful efficiency of the team (Suriansyah, 20I4).

While the supervision on site 2 was also carried out by the principal who monitored the teaching and learning activities in the field to see first hand the progress of each child, he was also active as homeroom teacher B. The principal also conducted monthly and semester evaluations to control the learning process. There is no control from the director of Tahfizh Plus Khoiru Ummah School directly to the field, but he directly controls it to the principal and quality assurance.

At the stage of supervision or controlling, it can affect the management planning process that will come, because by carrying out supervision means that it has conducted an evaluation on the ground to find out the weaknesses and errors that occur in order to be corrected in the management process in the future. Therefore, supervision must be done as well as possible so that the goals achieved can be realized. Supervision is a systematic effort in setting standards of implementation with the aim of planning, designing a feedback information system, comparing real activities with standards, determining and measuring deviations and taking corrective actions that ensure that all resources owned have been used effectively and efficiently.

Evaluation of Islamic aqeedah curriculum learning at STP TK Khoiru Ummah Banjarmasin is conducted on a daily, weekly, monthly basis, until the semester which ends with the distribution of student report cards. Completion of student progress reports is carried out independently by the teacher, based on daily progress notes in the connecting and anecdotal books (for teachers who implement them). TK Khoiru Ummah Banjarmasin also always provides simple rewards, as a form of teacher appreciation to students for their efforts to develop to be better from all aspects.

\section{Evaluation of Learning in the Islamic Aqeedah Based Curriculum}

While the evaluation of Islamic aqeedah based curriculum learning at the Tahfizh Plus TK Khoiru Ummah Banjarbaru School was carried out in several parts, namely: (I) Management Evaluation between Director, Principal, Public Relations and Quality Assurance. (2) Monthly evaluation between the Principal and the Teacher. (3) Final semester evaluation after distribution of report cards.

Student evaluations were only conducted at the end of the semester when the distribution of report cards, no anecdotal records were used, all negative events that occurred in the field, were spontaneously evaluated by the teacher and the principal. Teachers also swear back at the beginning of learning to review and know the level of student understanding of the material that was delivered the previous day. The evaluation of students written in report cards is done by the homeroom teacher and parents of students based on the components of development that become the reference and assessment categories that have been established such as not developed, developing as expected, developing as expected and developing very well as examples of report cards. So, every parent of the student is asked to come to school facing the homeroom teacher, to fill out the student development report card together.

Because the development of students at school and at home must be a unity to produce conclusions the results of perfect development, given the condition of children in school and at home can be different. And to unite perceptions and knowledge about the child in a comprehensive and detailed manner, the teacher and parent must collaborate.

As according to the National Association of Children's Education, assessment is the process of observing, recording, and documenting what children do, and how they do it as a basis for various educational decisions that affect children.

Assessment includes various steps, those are collecting data on children's development and learning, determining the importance of the program in considering program objectives, incorporating information into planning for individuals and programs, and delivering findings to the child's family and other relevant parties. Child progress assessment is integrated with the curriculum and teaching. In the PAUD program, a variety of procedures for evaluating children's progress are used to: (I) Design instructions for each child and group. (2) Communicate with the child's family. (3) 
Identifying children who may need special treatment or intervention. (4) Inform the development of the program (Santi, 2009).

\section{Factors that Influence the Implementation of the Is- lamic Aqeedah Based Curriculum}

The factors that influence the implementation of this curriculum are parents, the community and the government. Implementation of the curriculum involves many factors such as attitudes, thought patterns, perceptions, philosophical assumptions, feelings of teachers and teacher groups and school culture, very strategic if continuous clarification is made about various aspects of changes that will occur if the curriculum is implemented. Fullan identifies important factors that influence the success of curriculum implementation, namely the implementor must understand the characteristics of the changes that will be made. Often people reject change because they have not understood the change comprehensively, so they do not see the benefits of curriculum change for schools.

Another factor relates to the uncertainty of the difference between what the teacher has done over the years according to the old curriculum and the new curriculum. If the difference is not so great, there is little that needs to be clarified to the teacher as a curriculum implementer. But in other cases if the curriculum undergoes major changes, the experienced teachers will also have difficulty implementing it, as it takes a long time to learn it.

Another often forgotten strategic factor is the improvement of teacher professionalism before the implementation of the new curriculum. Moreover, the socialization of the new curriculum is only through a number of upgrades and workshops. Research has consistently revealed the need for face-to-face and person-to-person interactions to convince the comprehensive understanding of teachers on the implementation of the new curriculum. To acquire new knowledge and skills as well as new attitudes in curriculum, it is not enough to justify a glimpse, but it requires socialization of quality, usefulness, and practicality.

Teachers need to do something for their class, manage classes well, use learning by giving examples and not examples, and improving learning outcomes so that developments on aspects of religious and moral values can flourish well, and can distinguish what good and baddeeds. Using example and non-example learning models with audio visual media variations can improve the development of children's religious and moral values in differentiating good and bad deeds. So the result of this research is suggested to be an alternative to creating an innovative learning. So that creating an active and fun learning course can increase the quality of learning outcomes (Metroyadi, 2017).

The results of cross-site data analysis can be seen in the following explanation:

This study has presented data on research findings at Tahfizh School Plus TK Khoiru Ummah Banjarmasin and Tahfizh Plus TK Khoiru Ummah Banjarbaru School. To conduct this cross-site analysis, researchers will explain the conclusions of the propositions from both sites:

\section{Conclusion Site Proposition I}

Based on the results of the documentation and interviews with the Headmaster above, the researcher can conclude learning planning on the curriculum based on aqidah Islam that is (I) The Manager, Headmaster and All Teachers must follow the Education Training consists of 3 stages, conducted by the central Khoiru Ummah such as a) Training on Curriculum based on Islamic Aqidah, (b) Training on learning SOP, (c) Training on Language Workshop; (2) The Foundation's Managers, Headmaster and Teachers make the modified academic calendar from the central Khoiru Ummah; (3) Headmaster and Teachers make a schedule of learning (4) Teachers are required to make SKH in accordance with the direction and guidance given in Training. (5) Headmaster and teachers always hold internal meetings before implementing talqiyanfikriyyan based learning to prepare everything necessary.

Implementation of a curriculum based on Islamic Aqeedah ie the headmaster has organized a curriculum based on Islamic Aqeedah by making planning, assigning a task to implement Islamic Aqeedah-based curriculum on learning and evaluated. The headmaster along managers also make improvements and innovations in order to help schools achieve their target or learning goals in Khoiru Ummah.

Implementation of Islamic Aqeedah-based learning there, researchers can conclude that they use discovery learning strategies, or learning by doing, or they are commonly referred to as 'talqiyyanfikriyyan' because the addition of talqiyyanfikriyyan method is a learning by doing strategy integrated into aqidah Islam. The learning media they use in accordance with the theme being studied, for example: Cooking Class, the media they prepare are cookware, and the ingredients to be cooked. Researchers can see for themselves, that in such activities, the children actually cook themselves 
with enthusiasm, as well as peeling and cutting their own materials with good motor skills.

Supervision is conducted directly or indirectly by the principal and the founder of the foundation. Sometimes the headmaster is also a substitute for a teacher who is absent, so the headmaster can learn and experience firsthand the obstacles experienced by teachers in the field.

Evaluation of Islamic Aqeedah-based curriculum learning is done daily, weekly, monthly, up to half of which ends with the distribution of students' report. Student progress reports in the form of a raport, created by the guardian based on the notes of the student's daily development and through the student's liaison book.

Factors affecting the implementation of this curriculum are more coming from parents and the community. Where parents are busy working and environment that does not give a good example to early childhood.

\section{Conclusion Site Proposition 2}

Learning planning based on the Islamic Aqeedah curriculum at STP Khoiru Ummah Banjarbaru are (I) The Managers, Principals and All Teachers are required to follow the Khoiru Ummah Education Training; (2) The Foundation's Managers, Principals and Teachers make the modified academic calendar from the central Khoiru Ummah; (3) Principals and Teachers make scheduled learning and planning lessons together once every month (4) Principals and teachers always schedule internal meetings every month to semester; (5) Schedule management meetings once a

Therefore, through the Islamic Aqeedah-based curriculum, students will gain knowledge based on direct experience based on the aspects of faith or obedience. If the Islamic aqidah element is supported by character or personality in accordance with the Islamic law, then it is perfect that religious education enters into the students inwardly and outwardly. As the research on religious-based character education models implemented by Islamic schools shows that all components or school communities including parents are running religious-based character education, thus becoming a tangible example for all students(Cinantya, Suriansyah, \& Asniwati, 2018).

Because if children have Islamic characters within themselves with the foundation of faith in their hearts, children will learn how to value people, even respect their non-believers. Teachers teach or add the following strategies to widen the child's tolerance, month with the Director, Principal, Public Relations and Quality Assurance.

To organize the course of learning in this Islamicbased curriculum, he devoted his duties to all teachers and employees. In the course of their learning, they use learning learning discovery strategies, or learning by doing, or they commonly call 'talqiyyanfikriyyan' because the addition of the talikiyyanfikriyyan method is a learning-by-learning strategy that is integrated into the Islamic aqeedah. And the learning media they use fit the theme being studied. Examples: instant noodle experiments, the media they prepare are instant noodles, water, betadins and containers. These activities have a very significant effect on children who are accustomed to eating instant noodles, which are proven by parents themselves. The supervision technique of the principal by monitoring the activities of the teaching and learning process in the field to directly see the development of each child, he is also active as a TK B classmaster so direct experience of the learning process is carried out, and the principal also conducts monthly and semester evaluations to control learning process.

The evaluation of curriculum based on Islamic Aqeedah is done in several parts, those are: (I) evaluation of management between Director, Headmaster, Public Relation and Quality Assurance. (2) monthly evaluation between Principal and Teacher. (3) final evaluation of the semester after the raport division. While the factors that influence the achievement of learning goals are from teachers and parents.

those are (I) the teacher introduces good qualities, 2) the teacher introduces the nature of religious tolerance; (3) teachers provide stimulation for children to think about good qualities; 4) teachers give stimulus for children to think religious tolerance, 5) teachers make children feel the benefits of religious tolerance (Zain, Saleh, \& Noorhapizah, 2018).

The formation of the character will be determined not only on the strength of management in the school organization unit concerned. The power of management depends largely on the quality and strength of the principal as a leader (Suriansyah, 2015).

Cross-site analysis in this study is based on the results of the above research findings. The researcher can conclude that the implementation of Islamic aqeedah curriculum in the Khoiru Ummah School of Tahfizh Plus TK Banjarmasin and Banjarbaru has made changes 
and updates to the concept or view of education. Where they use their own curriculum, which is integrated with the government curriculum. They take important points for early childhood and remove components that they think are burdensome for children. After finding the core components that they want to adopt, they add another important component, which does not exist in the government curriculum such as Islamic law. Until the birth of the curriculum concept called the Aqeedah Islamic Early Childhood Education Curriculum.

As explained previously, that the nature of the implementation of the curriculum resulted in a change in the quality of student learning to suit the educational goals. This means that the implementation of the curriculum is a process of change to obtain results that are close to achieving ideal educational goals. Based on that, all curriculum work, from the design, implementation or implementation and evaluation is a cycle of Changde (Ansyar, 2015).

Therefore, this cross-site analysis produces the following things: (I) learning planning in the Islamic aqidah based curriculum has a modified academic calendar based on the Khoiru Ummah curriculum, determining the learning themes included in the academic calendar, making schedules learning according to the conditions of each school, and making daily activity plans with a very systematic and selected process. (2) organizing learning in this curriculum, namely by creating an organizational structure, which then in detail the headmaster distributes tasks to all teachers and em- ployees for the implementation of daily learning. (3) The implementation of learning uses discovery learning or doing by doing strategies which they commonly call the 'talqiyyanfikriyyan' method by integrating all knowledge into Islamic aqeedah, the media used are real media or the facts are directly in accordance with the predetermined themes. (4) controlling that they do is internal supervision carried out by the principal and chairman of the foundation and external supervision carried out by khoiru the central ummah. (5) evaluations carried out for the implementation of learning, namely by scheduled routine meetings between teachers, principals and managers of the foundation. While the evaluation of students is done through a connecting book, daily or weekly notes that are carried out by the teacher on student development, which is then used as the basis for filling out the report cards that will be reported at the end of each semester.

All the process of implementing the curriculum they are undergoing is to achieve the vision of Khoiruummah to be a representation of Islamic Aqeedahbased educational institutions, which is at the forefront of giving birth to a generation of leaders of noble civilizations (Islam).

Therefore, the concept of Islamic faith-based education must be broadcast to all parents, teachers and the community to jointly realize the generation of the best ummah who have moral or noble character.

The following are the results of the implementation of the Islamic Aqidah-based curriculum in the form of drawing grooves:

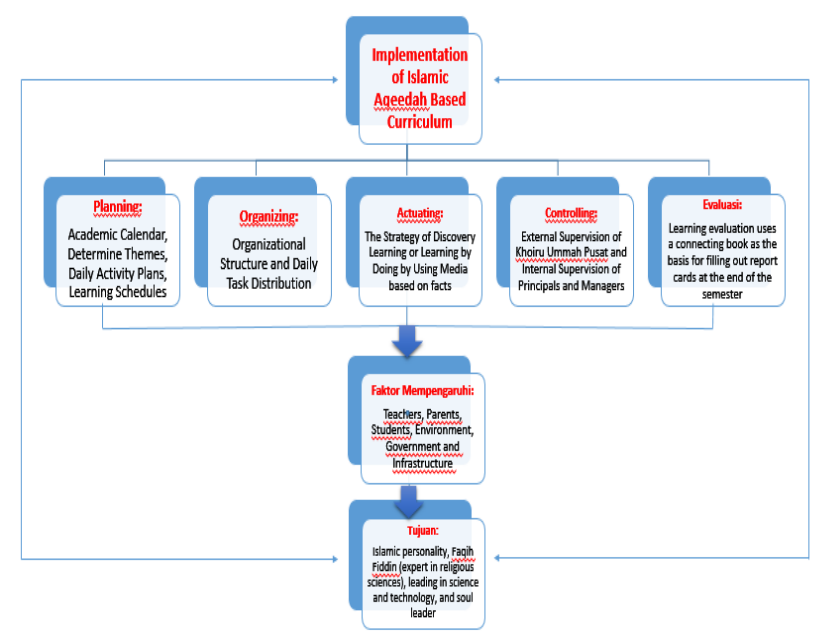

Figure 2. Flow of Implementation of Islamic Aqeedah Curriculum 


\section{Conclusions and Recommendarion}

a. Learning planning is carried out by creating an academic calendar that is modified based on the curriculum of the central Khoiru Ummah, making a learning schedule according to the conditions of each school, and making a daily activity unit.

b. Orginizing the implementation of this curriculum is that each school has a different organizational structure, which then in detail the school principal distributes tasks to all teachers and employees for the implementation of daily learning.

c. Implementation of learning by using discovery learning or learning by doing strategy which is called "talqiyyanfikriyyan" method by integrating all knowledge to Islamic aqeedah, regardless of the medium used is the real media or in fact directly correspond to a predetermined theme.

d. The form of controlling they do is an internal form of supervision or supervision carried out by the principal and the head of the foundation, both directly and indirectly.

e. Evaluation of learning carried out using a connecting book or diary that will become the basis for filling out report cards at the end of the semester. The school also scheduled regular meetings for teachers and managers of the foundation to find out developments and obstacles that occurred in the field and then find solutions together.

f. The factors that influence the implementation of this curriculum are parents, the community and the government.

Suggestions for schools are to improve the administration system and school data archiving, to make structured and patterned learning planning based on competencies to be achieved, to seek a deeper emphasis on teachers and parents, to always communicate about Islamic aqeedah intensively to children. As tahfizh organizer school, to improve teacher's ability in reading Quran by doing a target, until the teacher could get a shahadah or graduation certificate from the ummi method manager, to do innovations that can make children more attentive and enthusiastic about learning, for parents to always support every school activity and help schools to realize the school's vision and mission, by applying the concept of Islamic aqeedah at home to all children. To the community: to always provide good examples and role models for early childhood.

\section{Acknowledgment}

The authors thanks to Graduate Program of Teacher Education for Early Childhood Education, Universitas Lambung Mangkurat, Banjarmasin for supporting this research.

\section{References}

Andriyani, E., Ngadimun, \& Suriansyah, A. (2018). Character Education Management. IOSR Journal of Research \& Method in Education (IOSR-JRME), 8(6), I3.

Ansyar, M. (2015). Curriculum: Nature, Foundation, Design \& Development. Jakarta: Kencana.

Cinantya, C., Suriansyah, A., \& Asniwati. (2018). The Model of Religion-Based Character Education (Multi-Site Integrated Islamic PAUD Sabilal Muhtadin and PAUD Islam Mawaddah Banjarmasin, Indonesia). European Journal of Education Studies, 5 (7), 10.

Haenilah, E. Y. (20I5). Curriculum and Learning for Early Childhood Education. Yogyakarta: Media Akademi.

Metroyadi. (2017). Efforts to Develop Aspects of Religious and Moral Values in Differentiating Good and Bad Actions Using Examples Non Examples with Audio Visual Media Variations in Group B Children in TK Aisyiyah Bustanul Athfal 3 I Banjarmasin. Sagacious Jurnal Ilmiah Pendidikan dan Sosial Vo. 4 No. I, IO-II.

Mulyasa. (2004). Become a Professional Teacher. Bandung: Remaja Rosdakarya.

Safitri, M. E., Ahmad, K. I., \& Saleh, M. (2018). Development of Child Independence Through Model Picture and Picture, Examples Non Examples Model and Practical Method Directly Activities of Learning Practical Life in Group B Kasih Ibu Kindergarten, Banjarmasin, Indonesia. European Journal of Education Studies, 5 (7)., 77.

Salasiah, Asniwati, \& Effendi, R. (2018). Instilling Character Values in Early Childhood in The Perspective of Curriculum and Parenting (Multi-Site Study in PAUD Islam Sabilal Muhtadin and PAUD Mawaddah, Banjarmasin, Indonesia). European Journal of Education Studies, 5 (7)., $4 \mathrm{I}$.

Santi, D. (2009). Early Childhood Education: Between Theory and Practice. Jakarta: Indeks.

Sugiyono. (2017). Qualitative Research Methods: for Research That is Explorative, Enterpretive, Interactive and Constructive. Bandung: Alfabeta. 
Suhaimi, \& Rinawati, Y. (2018). Management of Character Education Curriculum at Vocational High School 2 Kandangan. Advances in Social Science, Education and Humanities Research, Volume 274, 273.

Sukriani, Huda A.Y, M., Arifin, I., \& Suriansyah, A. (2017). The Implementation of The Islamic Schools Resources Total Quality Management in Banjarmasin, Indonesia. Journal of Social Sciences (COES\&RJ-JSS), 6 (I), I35.

Suriansyah, A. (20I4). Relationship Between School Culture, Communication, and Work Commitment to The Performance of Public Elementary School Teachers. Cakrawala Pendidikan No.3, 359.
Suriansyah, A. (2015). Principal, Teacher, Parent and Community Leadership Strategy in Forming Student Character. Cakrawala Pendidikan, Th. XXXIV, No. 2, 242.

Torang, S. (2016). Organization and Management (Behavior, Structure, Culture \& Organizational Change). Bandung: Alfabeta.

Zain, A., Saleh, M., \& Noorhapizah. (2018). Strategy for The Development of Religious Worship and Religious Tolerance at Widya Dharma PAUD in Banjarmasin City, Indonesia. European Journal of Education Studies, 5 (7), 89. 